\title{
Celeng Ngelumbar Metafor Penambangan Eksploitatif Pasir
}

\author{
I Wayan Setem ${ }^{1}$, Pande Made Sukerta ${ }^{2}$, Sardono W. Kusumo ${ }^{3}$, M. Dwi Marianto ${ }^{4}$ \\ ${ }^{1,2,3,4}$ Program Studi Penciptaan dan Pengkajian Seni Pascasarjana Institut Seni Indonesia Surakarta
}

wayansetem@isi-dps.ac.id

\begin{abstract}
Aktivitas penambangan eksploitatif pasir di Kecamatan Selat telah memicu peningkatan pertumbuhan sektor ekonomi, namun masyarakat tampaknya tidak pernah sadar dengan dampak kerusakan lingkungan yang ditimbulkan. Fenomena penambangan eksploitatif pasir tersebut menjadi ide dan gagasan pokok kekaryaan. Setelah melakukan observasi pengkarya mendapat pemahaman dan insights yang menjadi pemicu proses kreatif. Problimatikanya dinyatakan ke dalam bentuk bahasa rupa menggunakan metode penyangatan/hiperbola. Proses mewujudkan kekaryaan mengunakan metode pendekatan dan langkah-langkah kreatif melalui tahapan terstruktur, spontan dan intuitif. Metode yang dipergunakan telah menghasilkan elaborasi yang unik dari semua komponen imajirial sehingga melahirkan gagasan dan metafor yang kreatif. Perwujudan karya dibuat atau digagas di studio kemudian dipindahkan atau dirangkai di sekitar wilayah areal penambangan. Hubungan antara lokasi presentasi dan masyarakat mampu menjadi sebuah kekuatan tersendiri karena sesuai dengan konteks persoalan. Target kekaryaan tidak hanya sebagai ekspresi individual yang terbatas pada persoalan estetika namun menjadi cara atau alat untuk menyebrangkan (mengkampanyekan) isu lingkungan. Penciptaan seni adalah sebagai modus yang mampu untuk menginspirasi masyarakat agar tergugah secara kolektif maupun individual untuk berpartisipasi dalam upaya pelestarian ekosistem.
\end{abstract}

Kata kunci: Tukad, penambnagan eksploitatif pasir dan celeng

\section{Celeng Ngelumbar (untied pig): Metaphor of Exploitative Sand Mining}

The exploitative sand mining in Selat District contributed to the economic growth; however, the local people were never aware that it had caused the environment to be degraded. The phenomenon of the exploitative sand mining is used as the theme and subject matter of an art creation. From what was observed by the artist, an insight into something contributed to a creative process. The problem was reflected in the form of language using the method of hyperbole. The art creation was created using the structured, spontaneous and intuitive creative steps and method which led to a unique elaboration of all the imaginary components and a creative metaphor and concept. The creation was designed in a studio before it was moved to or arranged around the mining area. The relation between the location of presentation and people could become a specific strength as it was in accordance with the context of the subject matter. The target of the art work did not only constitute an individual expression which was limited to the matter of common aesthetics but it was also used as the way of and the tool for transmitting (campaigning) an environmental issue. The art creation could be used to inspire people, as individuals and groups, to participate in the attempt made to preserve the eco-system.

Keywords: River, exploitative sand mining, and celeng (pig)

Proses Review : 1 - 31 Maret 2018, Dinyatakan Lolos: 10 April 2018 


\section{PENDAHULUAN}

Pengalaman pribadi merupakan satu pilihan masuk menuju sebuah proses kreasi penciptaan seni. Pengalaman masa kecil "bersentuhan" dengan sungai (selanjutnya ditulis $t u-$ kad) di desa tempat kelahiran (Selat, Karangasem, Bali) memunculkan dialog dalam batin. Realitas tukad pada tahun 1980-an yang masih lestari yang dimanfaatkan sebagai sanitasi, sumber irigasi, lumbung gizi keluarga, dan tempat diselenggarakan upacara melasti, mapag toya bagi karma subak, bayun pinaruh, nganyut abu jenasah saat upacara ngaben. Hal itu disebabkan karena Kecamatan Selat merupakan daerah tangkapan air sehingga tukad-tukad mengalirkan air dengan debit yang besar dan jernih. Di sepanjang aliran air berbagai jenis biota hidup berlimpah. Tebing dan bantarannya ditumbuhi pepohonan dan hutan bambu. Begitu juga di tepian tumbuh rumput gajah, glagah, alang-alang, sebagai tempat hidup berbagai spesies burung.

Kelestarian ekosistem dekade 80-an, tak lepas dari kekuatan budaya yang bersandar pada sistem adat, diimplementasikan dan ditaati secara luas dalam kehidupan bermasyarakat. Dilandasi kehidupan sangat dekat dengan lingkungan alamiah dan praktik-praktik ritual yang kompleks terkait Hinduisme-Bali, masyarakat yang menjunjung sistem adat sangat percaya dengan konsep keseimbangan dan keharmonisan kosmos. Keseimbangan dipercaya sebagai sumber kebahagiaan yang direfleksikan dalam keharmonisan hubungan antara manusia dengan Tuhan-nya; manusia dengan manusia; dan manusia dengan lingkungan alamiah sekitarnya.

Seiring dengan kemajuan dalam bidang pembangunan sebagai bentuk pertumbuhan dan perkembangan di Bali seperti akomodasi pariwisata, pusat perkantoran, dan perumahan maka sumberdaya alam, yakni pasir dan batu sangat diperlukan. Banyak tempat yang memiliki potensi pasir dan batu vulkanik menjadi incaran untuk lahan pertambangan seperti di Daerah Aliran Sungai (DAS) Unda.

Awalnya pengerukan material pasir secara masif memakai alat-alat berat dilakukan di Gunaksa, Klungkung, Bali yang merupakan hilir Tukad Unda. Setelah overeksploitatif tempat tersebut ditinggalkan begitu saja oleh pengusaha tambang dan kini meninggalkan "danau-danau" kecil di sana-sini. Dampak negatif dari penambangan tersebut, yakni lingkungan fisik pada tukad aktif mengalami perubahan yakni permukaan semakin lebar, berpindahnya aliran air dan runtuhnya tepi tebing, sehingga mengakibatkan erosi. Begitu juga terjadinya perubahan permukaan lahan (lanskap), yaitu bekas galian lubang besar yang digenangi air dan menjadi tempat bersarangnya nyamuk akan menjadi sumber penyakit. Dari ditutupnya penambangan di Gunaksa banyak wacana muncul untuk merehabilitasi tempat tersebut, namun sampai kini tidak satupun ada yang terwujud.
Setelah penambangan pasir di Desa Gunaksa, Klungkung dinyatakan ditutup, maka pengerukan beralih ke wilayah lereng Gunung Agung, yakni pada tukad-tukad di Desa Sebudi dan Desa Pering Sari yang merupakan hulu dari Tukad Unda. Para investor berdatangan melakukan penambangan besar-besaran dengan memakai alat-alat berat (peralatan modern yang bisa berproduksi 24 jam dan mampu menggali dalam jumlah ratusan ton) memerlukan ketersediaan lahan yang sangat luas sehingga eksploitatif terus bertambah bukan saja pada alur dan sampadan tukad tetapi sudah melebar ke tegalan, hutan rakyat, dan hutan lindung. Rona awal lahan yang sebelumnya kebun tanaman budidaya dan pepohonan produktif lainnya dijadikan lahan pertambangan untuk memperoleh material pasir dan batu vulkanik.

Sejak dikembangkan penambangan pasir, masyarakat setempat mulai beralih dari pekerjaan pokoknya sebagai petani ataupun pengerajin anyaman bambu, terutama bagi ibu-ibu yang dianggap pekerjaan lama tidak menjanjikan lagi bagi pemenuhan kebutuhan keluarga. Mereka beralih dan menggantungkan nafkah hidupnya ke penambangan (menjadi petani pasir). Beralihnya warga dari petani kebun ke "petani pasir" karena alasan klasik, yakni kemiskinan. Seringkali hasil panen untuk setiap komoditas yang diusahakan dan panen dua kali setahun tidak dapat memenuhi kebutuhan hidup dan mampu "mendesain" masa depannya. Dalam hal ini pendapatan yang diperoleh selain mencukupi kebutuhan primernya pangan, sandang, dan papan, juga kebutuhan lainnya seperti pendidikan, kesehatan, juga untuk melaksanakan aktivitas keagamaan dan sosialnya. Pendapatan yang diperoleh masih dalam standar batas miskin sehingga beralih profesi bekerja ke penambangan.

Dengan adanya penambangan pasir, ekonomi masyarakat sekitar memang mengalami peningkatan namun mereka tampaknya tidak pernah sadar dengan dampak kerusakan lingkungan yang sudah dan akan ditimbulkan. 'Sejauh ini, kami tidak merasakan ada dampak apa-apa dari aktivitas penambangan, yang kami rasakan adalah dampak positif, jika mungkin ada dampak negatifnya tapi kami masyarakat awam tidak terlalu mengerti tentang hal itu", kata Made Mangku Tirta, seorang pemangku dan tokoh masyarakat Desa Sebudi (wawancara, 12 Mei 2015).

Kurangnya sosialisasi adanya pelarangan penambangan pasir mengakibatkan masyarakat tambang tidak mengetahui penambangan pasir yang mereka lakukan adalah ilegal. Berdasarkan data Sekda Karangasem, ditotal ada 70 usaha gagian C skala besar. Dari jumlah itu hanya 13 buah beizin dan 57 buah tanpa izin. Sebagian besar yang tanpa izin ada desa Sebudi (Bali Post, Jumat Paing, 1 Agustus $2014: 3$ )

Menurut pengamatan pengkarya, penambangan eksploitatif pasir yang bersifat distruktif secara ekonomi jangka 


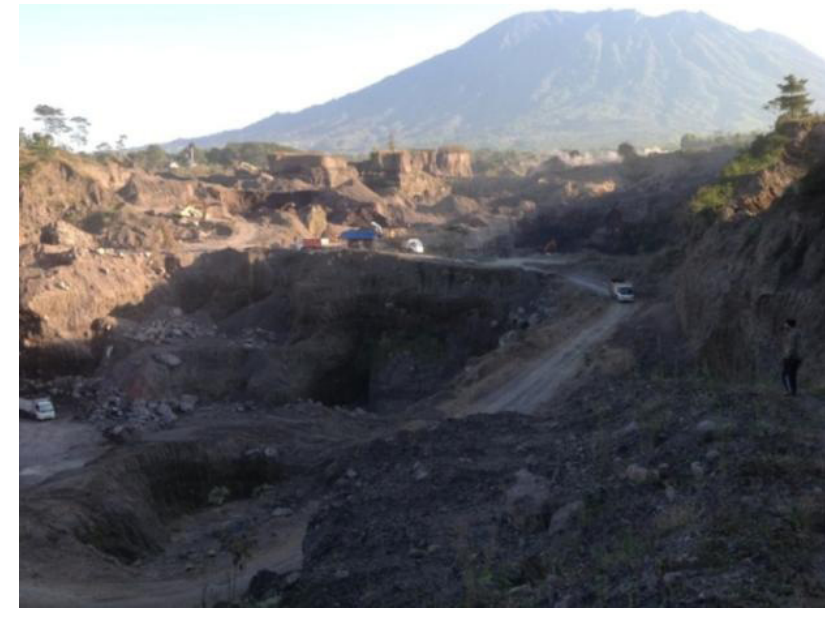

Gambar 1. Penambangan eksploitatif pasir menimbulkan lubang yang sangat luas dan dalam di Desa Sebudi, Selat, Karangasem (Dokumen : I Wayan Setem, 2016)

pendek memang memberi keuntungan tetapi dari aspek keberlanjutan ekosistem lingkungan alam sangat merugikan dan tidak akan bisa terbentuk seperti matra alam sebelunya. Akibat penambangan telah mengubah visualisasi bentang alam/topografi kawasan menjadi lanskap baru sehingga mengubah pula fungsi dan manfaat tukad yang sangat penting dalam menunjang kelangsungan kehidupan makhluk hidup. Berubahnya fungsi ekologi, saluran eko-drainase, dan saluran irigasi alamiah. Masalah lain yang dapat timbul adalah ketika penambang begitu saja meninggalkan kawasan penambangan tersebut tanpa upaya sedikitpun melaksanakan konservasi atau perbaikan lahan pertambangan lalu berpindah dan membiarkan lahan tersebut. Akhirnya dampak kerusakan lingkungan menjadi beban ditanggung oleh generasi pewarisnya.

Dampak penambangan juga menyebabkan perubahan emosional masyarakat terhadap tukad dalam kehidupan, baik secara skala (unsur pembersih badan dan pemenuhan gizi keluarga) maupun niskala (unsur ritual). Tukad tidak lagi menyediakan air sebagai sumber kehidupan spesies ikan dan beberapa tumbuhan siap petik sehingga tak terlihat aktivitas warga menangkap ikan, memetik sayur kece$k u$, dan kangkung. Beji (pancuran suci) tanpa air sehingga sumber air sebagai tirta pengelukatan dan tirta pengentas tak lagi didapat dari tukad melainkan tergantikan dengan air sumur yang digali pada masing-masing pekarangan atau air dalam kemasan mineral. Begitu juga Upacara Bayun Pinaruh dan Melukat tak lagi dilakukan di tukad yang kini kondisi debit airnya sangat kecil bahkan sudah kering dan rusak.

Dari realitas krisis lingkungan akibat penambangan eksploitatif pasir seperti tersebut di atas, seni sebagai ungkapan atau media ekspresi dituntut untuk turut memberikan kontribusi penyadaran dan perbaikan secara langsung maupun tidak langsung. Seni tidak hanya menghibur (rekreatif), tetapi memiliki ciri transformatif yakni sebagai media menyebarangkan isu lingkungan yang unik, imajinatif, dan inspiratif. Pengkarya berusaha memberikan solosi dari ranah penciptaan seni dengan jalan baru melalui metode penciptaan yang dilandasi oleh eco-art yakni seni untuk menanggapi krisis ekologis.

Dalam pemahaman eco-art mempunyai proses kreasi dan landasan pemikiran yang bertujuan : (1) seni sebagai refleksi terhadap lingkungan dan melalui seni berinovasi untuk solosi permasalahan ekologis (interpretasi); (2) seni merupakan kerja kreatif pemanfaatan bahan ramah lingkungan dan proses daur ulang sampah (media); (3) seni sebagai aksi untuk tujuan memperbaiki lingkungan yang telah rusak (restoring); dan (4) seni sebagai gerakan bersama yang mengkaitkan seni terhadap realitas lingkungan sehingga terjadi interaksi (kalaborasi).

Landasan pemikiran eko-art dijadikan landasan berpikir dan berkonsep dalam upaya penciptaan seni dalam menyebrangkan isu ramah lingkungan, menumbuhkan kesadaran bahwa segala sesuatu yang ada di alam adalah kelindahan, kait mengkait, dan saling mempengaruhi. Alternatif pemilihan aksi simbolis (kekaryaan) dan aksi fisik (pemberdayaan), pemilihan lokasi sosialisasi di areal penambangan pasir dan di areal SDN 1 Amerta Bhuana sangat terbuka pada proses interaksi masyarakat, termasuk sesuatu yang tidak terduga sebelumnya yang mencul dari fenomena alam yakni erupsi freatik Gunung Agung.

Gagasan yang muncul dalam kekaryaan, tentu saja tidak serta merta mampu mengatasi masalah lingkungan yang makin kompleks khususnya dampak kerusakan ekologis. Namun sebagai upaya "membuat ruang dialog", dialog antara manusia dan alam, antara manusia dan Tuhan, antara fakta dan nilai, antara kesadaran dan materi, antara jiwa dan tubuh, antara subyek yang mengetahui dan obyek yang diketahui, dan antara 'aku' dan 'yang lain'. 'Celeng Ngelumbar Metafor Penambangan Eksploitatif Pasir”, merupakan gagasan untuk mengedepankan kembali kearifan lokal sebagai pondasi pemahaman atas pentingnya keberlanjutan ekosistem bumi.

\section{KONSEP KARYA SENI}

Persoalan bentuk transformasi dalam proses penciptaan seni menjadi sangat penting ketika pengkarya ingin menjelaskan adanya korelasi antara konsep atau ide dengan nilai kebentukan (artikulasi) karya seni yang diciptakan. Dalam hal ini ide/konsep seni bertitik tolak dari fenomena overeksploitatif penambangan pasir yang memiliki kaitan dengan dampak kerusakan lingkungan. Objek kerusakan lingkungan sebagai gagasan kemudian diolah dalam suatu ruang imajinasi berlandaskan pemikiran eco-art.

Impresi yang muncul dari kerusakan lingkungan, ditafsirkan ke dalam ide-ide kerusakan, kerakusan, dan disharmoni yang masih sangat abstrak dan bersifat mengambang. 
Abstraksi sebagai respon mekanis dari kesadaran, juga tidak dimaksudkan untuk mendistori realitas sehingga realitas menjadi lepas dan tidak terpahami, tetapi abstraksi pada tahap ini merupakan aktivitas pencaharian dan pembentukan ide-ide yang ingin diabadikan menjadi bentuk visual. Begitu juga pemahaman terhadap konsep estetik yang dibangun masih merupakan kilatan-kilatan pemikiran (insights) semata yang baru bisa ditata ketika pengkarya sudah mencapai kepuasan dalam penjelajahan artistiknya. Seliweran ide-ide yang muncul dan terbangun selanjutnya ditransformasikan dalam bentuk visual. Artikulasi visual itu menjadi "bentuk signifikan", jika memiliki citra yang semakna dengan ide-ide yang telah dikonsepsikan itu. Citra yang semakna itu bersifat metaforik, karena nilai korespondensinya diletakkan pada medan diologi antara alat-alat berat seperti excavator sebagai alat yang paling vital untuk mengeruk/menggali material pasir, merobohkan tebing, yang disepadankan dengan simbol kerakusan (celeng).

Dalam aktivitas perwujudan (artikulasi visual), abstraksi atas realitas kerusakan lingkungan yang berupa ide-ide kebentukan, ditransformasikan dengan idiom-idiom bahasa rupa yang sesuai dengan keinginan pengkarya. Hubungan antara simbol-simbol kerupaan (idiom-idiom, genregenre, dalam bahasa rupa) dengan realitas subject matter bukan bagaikan sebuah cermin melukiskan secara tepat (satu banding satu), tetapi menunjukkan adanya korespondensi ide-ide pada keduanya.

Hubungkan antara ide yang bertitik tolak dari sesuatu yang non-estetik (dampak kerusakan lingkungan dari penambangan) menjadi sesuatu yang estetik, karena persoalannya sudah menjadi lebih luas dari sekedar persoalan peniruan atau mengubah. Hal tersebut karena pada awalnya niat untuk membuat karya dituntun oleh prinsip peniruan, namun hasil akhirnya merupakan suatu ekspresi tanggapan terhadap subjek yang digarap (alat berat excavator dan celeng) dan karya-karya lainya sebagaimana yang pengkarya lihat dan sebagaimana harusnya model tersebut dilihat. Karya terwujud menggambarkan apa yang diketahui bukan seperti apa yang terlihat.

Begitu juga persepsi seni sangatlah berbeda ketika hendak bicara tentang realitas, justru dengan cara melebur dan menyatu dengan realitas itu sendiri. Dengan bahasa Gadamer, yang terjadi dalam persepsi seni adalah proses "bermain", yakni proses di mana Subjek dan Objek tidak ada lagi, yang ada dan menampilkan dirinya adalah "permainan itu sendiri" (Gadamer, 1975: 91-108). Dalam proses semacam itu maka logika yang berlaku adalah logika bisosiatif, segala hal bisa berkaitan dengan segala hal lainya. Kebenaran yang tampil dalam seni adalah kebenaran eksistensial / eksperiensial yang sering kali tidak terukur.

\section{METODE PENCIPTAAN}

Kekaryaan pada intinya adalah wujud dari hasil pengamatan secara holistik probematika penambangan eksploitatif pasir di Kecamatan Selat, Karangasem yang ditransformasikan menjadi aksi simbolik yakni kekaryaan. Untuk itu dibutuhkan metode pendekatan kreatif dengan dua pendekatan, yakni pertama, pengamatan melalui observasi lapangan terkait aspek lingkungan, aktivitas penambangan, gaya hidup, sosial budaya, dan kedua mengkompilasi serta memilah-milah hasil-hasil pengamatan yang menjadi "amunisi" ide-ide kreatif untuk diwujudkan menjadi kekaryaan.

Pengkarya ketika semakin intens melakukan pengamatan (deep listening) akan dapat mengalami percepatan gagasan. Dalam hal ini dibutuhkan kesadaran eksis (menjadi natural, hadir dan menyatu dengan objek amatan dengan kesadaran penuh). Ketika pengkarya ada di lokasi maka kesadaran meruang dan mewaktu dalam irama kosmos, harus hadir tanpa membawa beban kesadaran masa lalu dan masa yang akan datang yang belum jelas (moment saat ini adalah segalanya). Dengan menyatunya antara pengamat dengan yang diamati, maka "pintu akan terbuka". Suatu keterbukaan menuju hal-hal yang kita tak diketahui sebelumnya sehingga melahirkan kemungkinan-kemungkinan baru pada setiap situasi.

Untuk mewujudkan kekaryaan maka pengkarya meminjam metode penciptaan karya seni menurut Rider (dalam Tisna, $2010: 52$ ) yang nantinya juga disesuaikan dengan kebutuhan pengkarya.

Seni seperti tindakan kreatif, sangat cair, dan 'terbuka', dan tidak ada batasan yang tegas untuk memagarinya. Sebab terlalu banyak persilangan dan pertautan di antara keragaman manusia-seni, agama, teknologi dan sebagainya. Pertanyaan yang perlu dicarikan jawabnya, bukanlah: "Apa yang dilakukan seni sendiri ?", tetapi sebaiknya “Apa yang dapat dilakukan seni untuk mencapai yang terbaik". Metode di atas sangat relevan untuk penciptaan seni "Celeng Ngelumbar Metafor Penambangan Eksploitatif Pasir", yang dapat merangkum berbagai persoalan namun tetap fokus dalam tujuan pencapaian serta nilai-nilai penciptaan yang mencakup tahapan-tahapan terstruktur maupun langkah yang tidak terduga, spontan dan intuitif.

\section{Observasi}

Observasi diartikan sebagai kegiatan mengamati secara langsung, tanpa mediator, agar dapat melihat kegiatan yang dilakukan subjek tersebut. Observasi dilakukan pada lokasi penambangan pasir di Desa Sebudi dan Pering Sari, Selat, Karangasem dan pemilihan lokasi untuk presentasi yakni SD yang ada di sekitar kawasan penambangan pasir. Pada areal penambangan observasi yang digunakan adalah observasi keterlibatan pasif, dalam kegiatan pengamatan pengkarya tidak terlibat dalam kegiatan-kegiatan yang 
dilakukan oleh para pelaku yang diamati. Dalam observasi melibatkan indra penglihatan (mata), pendengaran (telinga), dan pembau (hidung).

Mata mengamati fenomena penambangan secara visual yakni dampak matra alam yang ditambang, alat berat yang dioperasikan, aktivitas penambangan, asap, debu, jaringan distribusi, visual kultur sosial budaya masyarakat di wilayah penambangan, dll. Telinga mendengar suara gemuruh alat-alat berat seperti excavator, bulldozer, mesin pemilah, truck, pemecah batu, benturan material tambang, dan suara-suara lain yang ditimbulkan dari fenomena aktivitas penambangan. Perekaman data dilakukan dengan teknik pencatatan secara lengkap dan akurat terhadap obyek amatan yakni realitas penambangan pasir, termasuk pengambilan dokumentasi foto dan video.

Pada tahap awal obsevasi posisi pengkarya berusaha netral, dalam hal ini pengkarya tidak dalam posisi menyetujui atau menyalahkan aktivitas penambangan, sehingga sebagai observer dapat melihat semua sisi dan menampung semua fakta secara netral. Namun setelah mengamati secara konprehensif lalu memahami realitas-realitas di lapangan di mana telah terjadi eksploitatif terhadap tukad dan daerah sekitarnya terjadi kerusakan secara masif maka pengkarya merasa sangat terhenyuh. Repleksi kerusakan alam dari dampak penambangan eksploitatif pasir yang terjadi seperti merasakan tubuh pengkarya juga mengalami kerusakan.

\section{Wawancara dengan narasumber}

Wawancara dilakukan secara langsung kepada beberapa buruh tambang, pengusaha tambang, warga, tokoh masyarakat, pemerintah, murid-murid, dan guru. Topik dari wawancara seputar dampak penambangan dari sisi ekonomi, sosial, budaya, lingkungan, hukum, dan harapan-harapan pasca tambang.

\section{Telaah karya seni sejenis}

Studi dari karya-karya sejenis terdahulu dari seniman-seniman panutan baik secara konsep maupun bentuk karya sebagai rujukan untuk bisa mencari posisi yang belum digarap dan menghindari duplikasi. Pertama, karya Tisna Sanjaya, "Pusat Kebudayaan Cigodewah: Revitalisasi Budaya dan Pemberdayaan Masyarakat Melalui Seni Lingkungan", 2011. Posisi karya seninya memiliki lingkup yang lebih konprehensif menegaskan seni bukan semata ekspresi pribadi melainkan kerja kumunal keseluruhan proses dan interaksinya dibagun secara kalaboratif. Kebermanfaatan dari proyek seni seperti itulah menimbulkan rangsangan ide kreatif untuk menjadikan SDN 1 Amerta Bhuana yang ada di wilayah areal penambangan sebagai laboratorium kecil melaksanakan aksi fisik berupa penataan sekolah dengan sentuhan seni lingkungan.
Kedua, karya Widya Poerwoko, "Eco-Art: Fungsi, Peran, dan Makna Bambu dalam Integrated Space Design, 2009. Karya ini diniatkan pada pembenahan lingkungan hidup sebagai refleksi atas kerusakan lingkungan alam di daerah Cangkringan, Yogyakarta dengan mengadopsi konsep survival silat dan seni lingkungan. Hal tersebut mampu menjadi model pijakan untuk penggarapan karya seni yang mampu menginspirasi pendekatan baru dengan mengejawatahkan pemikiran-pemikiran konseptual pembenahan lingkungan yang berorentasi pada ekspresi seni dan mampu memainkan peran kritis untuk perubahan kearah emansipatoris menuju kesadaran ekologis. Untuk itu maka pengkarya memilih alternatif kreativitas dengan 2 aksi yakni aksi simbolis (kekaryaan) yang dipertegas dengan aksi fisik (pemberdayaan).

\section{Kajian literatur}

Kajian literatur dilakukan untuk memperkuat konsep sebagai landasan, arah kekaryaan, dan tujuan penciptaan yakni peningkatan kesadaran lingkungan. Sedikitnya ada 5 buku utama yang menjadi rujukan sumber tertulis, yakni 1) Ekologi Pariwisata : Tata Laksana Pengelolaan Objek dan Daya Tarik Wisata; 2) Filsafat Lingkungan Hidup: Alam sebagai Sebuah Sistem Kehidupan; 3) Seni Rupa Penyadaran, 4) Ekokritikisme Sardono W. Kusumo, Gagasan, Proses Kreatif, dan Teks-teks Ciptaannya, dan 5) Art and Life Force: in a Quantum Perspective.

\section{Percobaan/Eksperimen}

Dari metode temuan konsep dan teori seni dilanjutkan dengan melakukan percobaan berbagai bahan yang sesuai dengan visi ekologis, teknik penggarapan untuk mencapai wujud karya yang sesuai dengan konsep penciptaan. Percobaan dilakukan secara intens untuk penguasaan teknik. Teknik inilah yang pada gilirannya nanti bisa membawa kemungkinan pada pengembangan gagasan (ide), mengolah kerumitan (kompleksitas komposisi), hingga berbagai kemungkinan tersebut menjadi bahasa ekspresi. Teknik merupakan ketepatan menggunakan bahan dan alat menurut karakter pengkarya untuk melahirkan kualitas artistik. Dengan teknik dan peralatan maka media diolah/ direkayasa untuk melahirkan keindahan bentuk.

Percobaan media yang lebih ramah lingkungan, bahkan memanfaatkan berbagai alternatif bahan sampah yang bisa didaur ulang seperti kertas, streofoam, plastik, daun kering, dan sebuk kayu. Sehubungan dengan pemanfaatan media alternatif, maka dalam percobaanya juga dibarengi dengan berbagai perlakuan teknik menggunakan peralatan dngan cara konvensional maupun tidak konvensional.

\section{Pewujudan}

Tahap pembentukan merupakan pewujudan dan penggalian berbagai aspek visual artistik dan penajaman estetika dengan kemampuan teknis maupun analisis intuitif. Pada tahap pembentukan, pengkarya menggali dan memanfaatkan nilai-nilai probabilitas dari berbagai aspek dan yang 
terkait dengan visual maupun teknik artistik lainnya. Karena dalam perwujudan melibatkan imajinasi, maka terjadi improvisasi untuk melahirkan berbagai kemungkinan baru terkait wujud purwarupa.

\section{PROSES PERWUJUDAN}

Pembentukan karya secara umum dapat dirangkum melalui beberapa tahapan sebagai berikut.

Menyediakan bahan dan alat untuk proses pengerjaan. Bahan yang diperlukan yakni : kawat loker, tali kawat, styrofoam bekas, bubur kertas, lem, dan sebagainya. Alat terdiri dari gergaji, berbagai jenis pisau, mesin gerinda, mesin bor, dan alat-alat pertukangan lainya.

Membuat rangka badan patung dengan kawat loker yang dibentuk sedemikian rupa sesuai model (sketsa terpilih). Kawat loker dibentuk dengan memotong, merangkai yang dipermanenkan dengan mengikat rangkaian rangka memakai tali kawat agar kokoh. Selanjutnya dibuat rangka tangan dan kaki yang bisa langsung tersambung di rangka badan atau terpisahkan (knockdown). Setelah rangka selesai maka dibuat kepala patung menggunakan styrofoam. Pemakaian bahan styrofoam agar bisa lebih mudah membentuk detail wajah (kepala) patung sesuai yang dikendaki. Jika sudah selesai maka kepala disambungkan di rangka kawat.

Pelapisan pertama adonan bubur kertas dilakukan tidak terlalu tebal menggunakan tangan hingga menutup keseluruhan rangka. Penutupan kedua dilakukan setelah lapisan pertama telah kering dan dilakukan tahap demi tahap. Pelapisan kedua dan seterusnya dilakukan setelah lapisan yang akan ditutup kering sambil memperbaiki bentuk anatominya. Agar permukaan lapisan adonan yang diterapkan pada rangka patung bisa rata (halus) diratakan memakai pisau palet.

Pengeringan karya bisa dilakukan dengan menjemur pada sinar matahari atau dianginkan. Waktu yang dibutuhkan untuk pengeringan sangat tergantung pada ketebalan lapisan adonan bubur kertas. Makin tipis lapisan maka pengeringan lebih cepat dan jika tebal perlu waktu sampai 1 bulan agar benar-benar kering. Ciri pengeringan sudah maksimal yakni berat karya akan lebih ringan karena hilangnya kadar air dan adanya perubahan warna menuju warna asli kertas karena unsur lemnya telah mengering.

Meratakan permukaan dengan menggunakan amplas, mulai dari amplas kasar sampai amplas lebih halus. Jika ada bentuk/yang tidak sempurna maka ditambah lagi dengan adonan bubur kertas atau dihilangkan/dibuang menggunakan gergaji atau pisau.

Pelapisan dengan kornis (compound) permukaan yang dikendaki hasilnya sangat rata dan halus. Pelapisan den- gan kornis dilakukan secara bertahap kemudian diamplas ulang, Jika belum juga rata, maka pelapisan dan pengamplasan dilakukan berulang-ulang hingga mendapat hasil sesui yang dikendaki.

Memberi warna dasar waterproofing/coatings dengan menggunakan kuas bulu soft. Pelapisan ini bermaksud untuk kedap terhadap air. Setelah proses warna dasar tadi selesai maka dilanjutkan pengecatan memakai kompresor dengan cat besi/kayu.

Untuk memberi aksen ekspresif pada bagian-bagian tertentu, ter-utama untuk memperkuat citra bentuk yang digambarkan maka ditambah dengan cairan stryofoam yang telah diencerkan dengan tiner atau bensin yang ditambahkan sedikt cat minyak.

Tahapan evaluasi dilakukan untuk merevitalisasi kerangka pemikiran/konsepsi dan visual (muatan, ekspresi maupun substansi) sehingga karya yang diciptakan menjadi padu/ harmoni dalam sebuah kekuatan estetik. Untuk hasil akhir maka diperlukan perenungan dan "dialog" pada karya.

Khusus untuk pengerjaan patung "Rumah Sida Rahayu" yang berbahan logam/besi pencipta menggunakan dua teknik pengelasan yakni pengelasan dengan alat las listrik dan pengelasan alat las karbit.

Untuk hasil akhir maka diperlukan perenungan dan "dialog" pada karya. Di sini karya kembali diamati dari jarak dekat maupun jarak jauh secara bolak-balik, kemudian direnungi bagian perbagian maupun keseluruhan apakah penataan elemen-elemen dan prinsip-prinsip penyusunan seni rupa sudah dapat menyampaikan ide serta gagasan. Pada proses ini terjadi penyempurnaan dengan menambahkan elemen-elemen yang bisa mendukung secara keseluruhan atau menghilangkan bagian-bagian yang dianggap berlebihan atau tidak perlu ditampilkan.

Mengenai penyelesaian sebuah karya, jangka waktunya tidak bisa diprediksikan. Sebuah karya kadang-kadang bisa rampung dalam hitungan waktu singkat atau lama dan bisa juga berujung pada kegagalan penyelesaian karya karena dalam proses kreatif melibatkan improvisasi. Di dalam mencipta pengkarya berpedoman pada persepsi batin (karya terwujud menggambarkan apa yang diketahui bukan seperti apa yang terlihat). Dalam konteks kerja tersebut pengkarya senantiasa memperbaharui pola pandang, dan berani melihat permasalahan dari berbagai perspektif, serta memandangnya "dari luar dan sekaligus dari dalam".

\section{WUJUD KARYA}

Karya-karya yang ditampilkan dalam penciptaan ini pada hakikatnya adalah sebuah bahasa dalam bentuk visual. Selain dapat dinikmati secara tekstual dalam tampilan artistiknya yakni keindahan unsur elemen seni, juga ingin 
mengkomunikasikan pemikiran secara kontekstual yakni kandungan isi atau pesan/makna.

Melalui penjabaran, maka dapat dirancang bentuk karya yang dirangkai dari bagian perbagiannya, yaitu:

\section{"Ngelumbar - ngelumbih : Rekam Jejak Perubahan- Lansekap"}

Pada bagian ini, audiens diajak untuk napak tilas apa yang pengkarya rasakan dari dampak penambangan eksploitatif pasir. Sebelas patung celeng dengan berbagai ekspresi yang metaforik tertata di areal bekas penambangan sebagai galeri, semua memetaforkan kerakusan dalam memanfaatkan sumberdaya alam berupa pasir vulkanik.

"Backhoe yang Bego". Secara sintaksis patung celeng merupakan ikon alat berat backhoe dan diinterpretasikan sebagai "pemangsa" lingkungan yang sangat bego (membabibuta). Backhoe merupakan bagian dari excavator (alat penggali) dengan sistem penggali tarik (pull shovel). Backhoe terdiri atas tiga bagian, yakni bagian atas atau revolving unit (bisa berputar), bagian bawah atau undercarriage (untuk berjalan), bagian attachment yang dapat diganti terdiri atas boom, stick dan bucket. Backhoe dipakai untuk penggalian. "Backhoe yang Bego" melukiskan aktivitas penambangan menggunakan alat-alat berat seperti backhoe yang beroperasi hampir 24 jam mengeruk material pasir, membongkar bebatuan, merobohkan pepohonan sekilas nampak seperti moster kesurupan menghancurkan tukad, tegalan dan bebukitan.

"Pees Beduda: Birahi Sang Predator", sosok patung celeng yang berdiri tegak menatap dengan air liur menetas. Sorot tatapan mata yang birahi di mana bebukitan, tukad, tegalan, bahkan hutan lindung yang mengandung material pasir vulkanik ditatap sebagai korban yang harus disantap, sebagai pemuas nafsu keserakahan.

“Kaung Ngelumbih", mengisahkan celeng pejantan (kaung) yang sedang menggali dan terus mengali. Kaung sebagai sosok sebagai aktor yang merusak lingkungan saat ini akibat kerakusan, ketamakan, kebuasan, kemalasan, kebodohan, nafsu dan lain sebagainya. Dengan demikian kaung menjadi sebuah penggambaran dari keburukan tingkah laku orang-orang saat ini yang semakin tidak memperdulikan kepentingan bersama dan kelestarian lingkungan.

“Komat'su-Komang Su Menimbun Lemak", menggambarkan oknum manusia yang menginginkan mendapat kekayaan dalam waktu singkat. Tegalan produktif, hutan rakyat, hutan lindung (tanam tuwuh) dikorbankan dan diluluhlantahkan untuk mendapat material pasir. Persoalan penambangan eksploitatif pasir seperti orang serakah yang terus memakan dan memakan sumber kekayaan alam. Kerusakan lingkungan yang diakibatkan dari aktivitas penam- bangan pasir secara masif sudah tak terelakkan lagi dan kondisinya benar-benar sangat memperihatinkan. Namun di sisi lain, aktivitas penambangan pasir tersebut menjadi bagian dari sumber kesejahteraan bagi warga sekitar. Bahkan aktivitas penambangan yang tidak berizin ini justru menjadi salah satu penopang Pendapatan Asli Daerah (PAD) Kabupaten Karangasem.

"Kaung Berbulu Emas", melukiskan bahwa dewasa ini perhatian masyarakat hanya dipusatkan pada eksistensi kekinian saja dengan segala upaya untuk mempernyaman hidup (hedonism). Manusia sedikit sekali yang memiliki perhatian kepada kelestarian lingkungan dan keadilan antar generasi, bahkan telah mengorbankan orang lain dan masa depan generasi mendatang. Manusia cendrung hanya mengejar tuntutan materi saja dan telah kehilangan nilai kemanusiaan. Manusia telah menjadi mesin kehidupan yang harganya bisa diukur dengan uang atau benda lainya. Penampilan dan gaya hidup menjadi ukuran keberhasilan, seperti kaung berbulu emas.

"Maestro Sumanto pun Kalah", Karya ini terinspirasi dari kejadian Kasatpol PP Karangasem, sering kali gagal saat menggelar sidak galian pasir ilegal di Desa Sebudi. Selama ini ada indikasi operasi sidak ke galian pasir selalu bocor ke pengusaha sehingga tanpa hasil. Tim Yustisi itu merupakan petugas negara, tetapi kalah dengan pemilik/ pengusaha galian pasir tanpa izin. Memang antara pengusaha dan aparat penegak hukum "kong kalikong" sehingga penambangan eksploitatif pasir tetap berlanjut walaupun melanggar hukum.

“Caterpillar-CatKiller", merupakan karya yang mengkritisi oknum eksploiter yang mendapatkan kekayaan dan kesenangan dengan cara mengorbankan kehidupan dan sumberdaya alam. Kekayaan alam yang semestinya untuk kesejahteraan rakyat telah berubah menjadi milik individu-individu, baik ditingkat rakyat maupun negara. Para investor melakukan penambangan kekayaan alam secara besar-besaran dengan memakai alat-alat berat (mesin modern yang bisa berpoduksi 24 jam dan mampu menambang dalam jumlah ratusan ton). Kebun bambu, salak, kebun kopi, dan tataman penghijauan lainnya lenyap untuk mendapatkan hasil-hasil tambang. Tidak ada lagi kearifan di dalam pengelolaan lingkungan, kearifan lokal diterabas demi memenuhi hasrat sesaat.

"Overdosis", Penjarahan terorganisir atas sumber daya alam semakin mengabaikan sendi-sendi hukum, keselamatan dan kelestarian lingkungan. Alam dieksploitasi sedemikian progresif hingga merusak ekologi. Penyimpangan dan peghianatan malah dengan luar biasa dilakukan dengan semena-mena mengekploitatif tukad bahkan lahan produktif berdalih suplai konsumsi. Terjadinya perluasan lahan galian menuju tegalan dan ladang penduduk mengingat keberadaan material pasir dan batu di tukad sudah semakin menipis. Kondisi ini menyebabkan pihak investor 


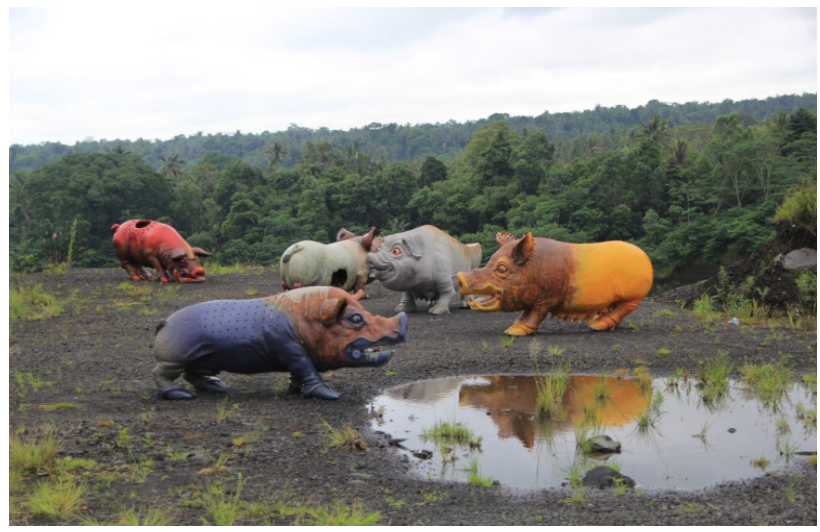

Gambar 2. Lokasi di Br. Lusuh Kauh, Peringsari, Selat (areal penambangan) tempat dipresentasikan "Ngelumbar-ngelumbih: Rekam Jejak Perubahan Lansekap" (Dokumen: I Wayan Setem, 2018)

mulai melakukan berbagai trik rayuan terhadap pemilik lahan yang dipridiksi di bawahnya berpotensi memiliki material pasir cukup banyak. Penambangan pasir yang serakah bahkan over dosis menimbulkan potensi air menipis akhirnya menjadi kerontang. Fakta kerusakan lingkungan telah nyata dihadapan kita: dari krisis air sampai dengan bencana-bencana alam yang menimpa akibat rusaknya ekosistim.

“Celeng Berjubah Putih", Secara semantik adalah seekor celeng bermotif sapi berjubah putih yang diibaratkan manusia yang jahat namun berkedok baik dengan mengkamuflasekan diri menjadi sesuatu yang baik bila dilihat secara kasat mata. Kerakusan memerah alam pasti akan menutupi rahasianya serapat mungkin seperti jubah kain putih yang untuk menutupi rahasia berdalih pembangunan.

"Rumah Sida Rahayu: Ketahanan Ekologis dan Manusia Kosmos"

"Rumah Sida Rahayu" dirancang sebagai satu konstruksi fisik yang dilandasi oleh kondisi lingkungan, pengetahuan, kepercayaan dan tradisi. Dengan demikian memiliki fungsi dan peran ganda selain berfungsi sebagai tempat pertemuan, bermain dan belajar juga bermakna sebagai sosio kultural yang merangkum pelbagai dimensi kondisi kekinian dari masyarakat.

"Rumah Sida Rahayu" mampu memancarkan kekuatannya lewat berbagai objek patung bayi, anak-anak dengan tetumbuhan di kepala serta perut dapat diamati setiap saat. Ilustrasi dari bentuk bagian ketiga ialah patung pendeta memegang genta yang disatupadukan dengan bunyi genta seorang pemangku saat sedang upacara syukuran yang disebut melaspas. Dari fenomena tersebut pengkarya ingin membangun kembali kesadaran tentang bagaimana menghargai alam.

Untuk mempresentasikan karya tersebut di atas maka ditetapkan 2 lokasi yakni : (1) pertama di Banjar Lusuh

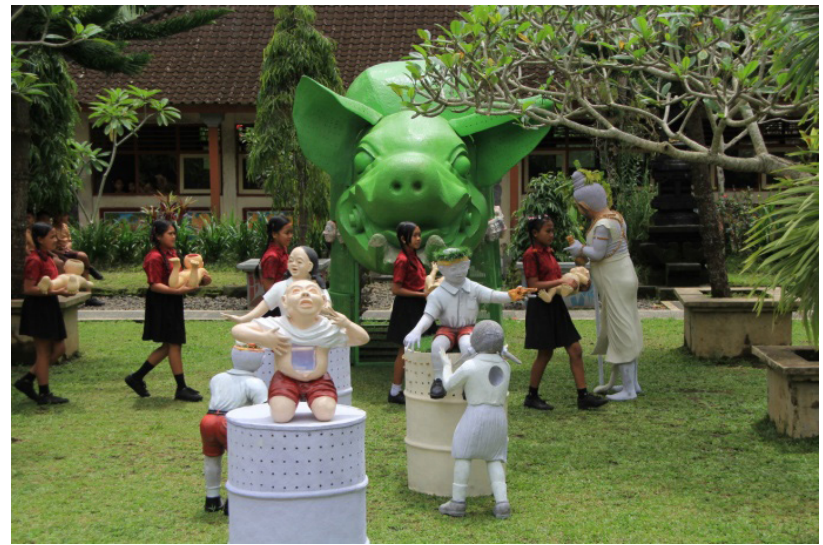

Gambar 3. Lokasi kedua pergelaran di SD N 1 Amerta Bhuana, Br. Muntig, Amerta Bhuana, Selat, tempat dipresentasikan "Rumah Sida Rahayu: Ketahanan Ekologis dan Manusia Kosmos” (Dokumen: I Wayan Setem, 2016)

Kauh, Peringsari, Selat (tepatnya di lahan bekas galian Batu Asah, Plemadon) dan 1 kedua di SDN. 1 Amerta Bhuana, Amerta Bhuana, Selat yang berada pada zona II saat Gunung Agung mengalami erupsi (aktivitas level IV). Penetapan lokasi tersebut berdasarkan faktor keselamatan, konteks karya dan teknis.

Lokasi pertama di Banjar Lusuh Kauh, pameran yang berlangsung di areal penambangan di mana aktivitas penambangan menjadi latar dari kekaryaan yang dihadirkan, antara latar dan wujud kekaryaan akan terjadi inter-relasi. Ketika karya hadir di sana pada kesempatan tersebut maka masyarakat menonton diri dan habitus mereka, bagaikan sebuah cermin yang merefleksikan bayangan dirinya. Sedangkan lokasi kedua di SD N 1 Amerta Bhuana sangat cocok untuk mempresentasikan karya karena memiliki areal halaman yang cukup luas. Selain itu juga memiliki ruang yang tidak difungsikan untuk proses pembelajaran yang pengkarya gunakan sebagai tempat penyimpanan secara permanen. Pada ruang ini akan ditata menyerupai museum kecil hasil-hasil kekaryaan, dokumentasi saat observasi lapangan, dan benda-benda lainnya terkait proses penciptaan yang bisa dimanfaatkan sebagai media pembelajaran tentang lingkungan (eco art). Begitu juga dengan memiliki halaman yang luas maka sangat cocok untuk memajang/menempatkan patung monumental (Rumah Sida Rahayu) sebagai simulator ketahana ekologi.

\section{SIMPULAN}

Proses kreasi pada dasarnya adalah proses pengolahan konsep tematik yang dipadukan dengan proses pengolahan media, untuk menghasilkan konsep artistik karya. Konsep tematik bertalian dengan referensi atau aspirasi akan nilai dan makna kehidupan dalam karya, sedangkan hal media adalah olah bahan serta teknik untuk menghasilkan demensi estetik. 
Target kekaryaan tidak hanya sebagai ekspresi individual yang terbatas pada persoalan estetika (keindahan rupa) namun lebih jauh karya menjadi cara atau alat untuk memahami persoalan atau kenyataan yang kita hadapi. Penciptaan seni adalah sebagai modus yang mampu memberikan transfer of knowledge dan menjadi pondasi awal mengajak masyarakat untuk menumbuhkan rasa kepeduliannya terhadap lingkungan. Seni sebagai alternatif kreatif yang berpihak pada ketahanan ekologi menjadikan wilayah seni menjadi hidup dan interaktif dengan masyarakat. Melalui seni seperti juga halnya ritual akan memunculkan daya hidup, hal tersebut bisa terjadi kalau ada kegembiraan dan seni sebagai tawaran utuk memunculkan daya hidup.

Metode yang digunakan untuk mendukung topik "Celeng Ngelumbar Metafor Penambangan Eksploitasi Pasir" telah dapat merangkul secara sistimatis pendekatan karya yang diacu, hingga berhasil membangun keutuhan penciptaan secara keseluruhan. Metode ini telah menghasilkan elaborasi yang unik dari semua komponen imajirial sehingga melahirkan gagasan dan metafor yang kreatif. Ciri ini dapat diamati dari makna yang tersirat pada karya yang diwujudkan, mengandung teks yang berbeda dari sekedar bentuk yang tampak secara visual. Lewat visual karya yang telah diciptakan, serta metafor yang digagas telah menunjukan narasi imajiner yang dapat dibaca sebagai jalinan makna yang berdemensi kritik.

Untuk memberikan penilaian tidak selalu terfokus pada hasil akhir dari karya yang dipresentasikan dalam pameran, namun penilaian proses penciptaan menjadi penting untuk dikemukakan. Dalam proses penciptaan terjadi interaksi dan pengalaman yang unik antara alam (areal penambangan serta dampak yang ditimbulkan), dengan masyarakat di sekitar lokasi penambangan (buruh tambang, pemilik tambang, anak-anak SD, tokoh masyarakat, LSM), seniman lain, dan tim kerja. Dalam setiap proses penciptaan terkandung nilai-nilai positif bagi kedua belah pihak berupa kesadaran, pengalaman, dan nilai-nilai baru.

Berdasarkan kesimpulan yang termuat di atas, maka pengkarya dapat mengajukan saran-saran yang bersifat konstruktif sebagai berikut:

Pertama, untuk masyarakat akademisi, penciptaan karya seni dalam berbagai aspeknya bersifat plural begitu juga media dan pemaknaannya selalu berubah sesuai kontek persoalan yang mendasari penciptaan. Seni ternyata sifatnya berkelindahan (saling berkait) dengan berbagai keberagaman antara seni murni, seni terapan, seni musik, performance art, dll. sehingga berpeluang bisa dikembangkan kearah jelajah kosa rupa yang semakin khas dan dinamis. Begitu juga dengan adanya pameran karya seni rupa yang dilakukan oleh pengkarya di halaman sekolah, bisa menjadi stimulus seniman lainnya untuk melakukan proses pameran bukan saja di gedung galeri tetapi memungkinkan digelar di berbagai tempat terkait dengan konteks kekaryaan.
Kedua, terhadap pemerintah untuk mengimplementasikan tata ruang (sesuai konsep tri hita karana) yang sudah ada dengan penyusunan zonasi pertambangan yang memuat lokasi-lokasi yang dicadangkan untuk penambangan berdasarkan keberadaan deposit bahan tambang dan pertimbangan ekologis. Pemerintah harus menutup penambangan pasir ilegal khususnya yang berada di zona tidak boleh ditambang. Penertiban penambang liar itu, mesti dilakukan bertahap dan tak bisa dilakukan secara kekerasan, namun dilakukan pendekatan, dan diberikan alternatif sumber penghasilan (kebijakan alih profesi yang tepat) bagi masyarakat dengan mengusahakan program-program rehabilitasi yang secara sosial dapat diterima dan bermanfaat bagi masyarakat.

\section{DAFTAR RUJUKAN}

Asdak, Chay. (2004), Hidrologi dan Pegelolaan Daerah Aliran Sungai, Gadjah Mada University Press, Yogyakarta.

Capra, Pritjof. (2001), Tao of Physics: Menyingkap Pararelisme Fisika Modern dan Mistisisme Timur, Jalasutra, Yogyakarta.

Darsoprajitno, H. Soewarno. (2013), Ekologi Pariwisata: Tata Laksana Pengelolaan Objek dan Daya Tarik Wisata, Angkasa, Bandung.

Marianto, M. Dwi. (Februari 2007), "Relasi Luar-dalam Antara Seni dan Metafor", dalam SURYA SENI Jurnal Penciptaan dan Pengkajian Seni, 3/01, Pascasarjana ISI Yogyakarta, Yogyakarta.

(2017), Art and Life Force: in a Quantum Perspective, Scritto Books Publisher, Yogyakarta.

Moelyono. (1997), Seni Rupa Penyadaran, Yayasan Bentang Budaya, Yogyakarta.

Keraf, A. Sonny. (2017), Filsafat Lingkungan Hidup: Alam sebagai Sebuah Sistem Kehidupan, PT. Kanisius, Yogyakarta.

Poerwoko, Widya. (2009), Eco-Art: Fungsi, Peran dan Makna Bambu dalam Integrated Space Design. Proposal Disertasi Karya Seni Doktor S-3 Program Pascasarjana Institut Seni Indonesia Yogyakarta.

Sanjaya, Tisna. (2010). Pusat Kebudayaan Cigondewah: Revitalisasi Budaya dan Pemberdayaan Masyarakat Melalui Seni Lingkungan. Disertasi Karya Seni Doktor S-3, Program Pascasarjana Institut Seni Indonesia Yogyakarta. 
Setem, I Wayan, dan A.A. Gede Yugus. (2013), Eco Reality. Laporan Hibah Penciptaan Dana DIPA Institut Seni Indonesia Denpasar.

Sudarma, I Wayan. (Agustus 2014), "Dampak Galian C Terhadap Lingkungan Alam dan Sosial Budaya Masyarakat Desa Peringsari Kecamatan Selat Kabupaten Karangasem." dalam JNANA BUDAYA, Media Informasi Sejarah, Sosial, dan Budaya, 19/2, Balai Pelestarian Budaya Denpasar.

Tanpa nama. (1 Agustus 2014) "Problmatika Galian C di Karangasem" Bali Post.

Tedjoworo, H. (2001), Imaji dan Imajinasi: Suatu Telaah Filsafat Postmodern, Kanisius, Yogyakarta.

Widaryanto, F.X. (2015), Ekokritikisme Sardono W. Kusumo: Gagasan, Proses Kreatif, dan Teks-teks Ciptaanya, PascaIKJ, Jakarta.

\section{Nara sumber:}

Tirta, I Made Mangku (61 th.), Wiraswasta, wawancara tanggal 12 Mei 2015 di rumahnya, Banjar Sebudi, Desa Sebudi, Selat, Karangasem, Bali. 